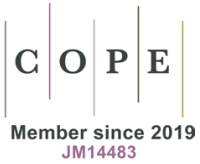

\title{
Svetlana Slapšak's \\ Feminist Essay: A Polygraph of Contemporary Culture
}

\section{Contemporary discussion on the essay. Introductory remarks}

The discussion on the changing and modifying role of the essay seems a major issue in the contemporary humanities. The purpose is not only to review and once more analyse the paths of the evolution of the essay as a genre, but, most of all, to reconsider/refresh - and certainly to update and enrich - the thinking about the essay from today's methodological perspective, as well as to examine its new modified contemporary instances. The genre has caused researchers many problems as the phenomenon has successfully avoided any definition or precise specifications ${ }^{1}$, yet this elusiveness of its form and its ability to produce various adaptations and permutations testifies to its intellectual appeal and resilience. Even the global attempt at

1 I am referring to the rich and exceptionally interesting literature regarding the essay. Cf. W. Hilsbecher, Esej o eseju, [in:] id., Tragizm, absurd i paradoks. Eseje, selection and introduction by S. Lichański, transl. S. Bałut, Warsaw 1972; М.Н. Эпштейн, ПАРАДОКСЫ НОВИЗНЫ. О литературном развитии Х1Х-ХХ веков, Москва 1988 (especially chapters: Эссеизмкак явление культуры, Эссеизация литературы и философи, Эссе и миф, Эссема и метафора); The Politics of the Essay. Feminist Perspectives, eds. R.E. Boetcher Joers, E. Mittman, Bloomington 1993; M.P. Markowski, Czy możliwa jest poetyka eseju?, [in:] Poetyka bez granic: Z Dziejów Form Artystycznych w Literaturze Polskiej, eds. W. Bolecki, W. Tomasik, Warsaw 1995, pp. 109-119; K. Chmielewska, Jak możliwa jest poetyka (eseju)?, “Teksty Drugie" 2001, issue 3-4, pp. 134138; R. Sendyka, Nowoczesny esej. Studium historycznej świadomości gatunku, Kraków 2006; R. Sendyka, Od kultury "ja” do kultury "siebie”. O zwrotnych formach w projektach tożsamościowych, Kraków 2015. 
discussing it and developing a huge English project which produced the monumental compendium titled Encyclopedia of the Essay ${ }^{2}$, edited by Tracy Chevalier - though providing many interesting outcomes and gathering an impressive material - still in many respects leaves readers craving for more. It was especially the case with minor literatures, e.g. Serbian (or other post-Yugoslav) literature, whose none of the female or male representatives was included in the encyclopaedia despite the fact that the area produces interesting phenomena. I obviously believe that one should recognise the multi-perspective interdisciplinary description of the genre and its strong organisation, as well as the discussion of its distant and more recent histories. However, even such an all-encompassing attempt at grasping the essay within the global scale, despite excellent entries prepared by outstanding specialists from various countries as well as the volume's impressive size (2191 pages in the 2006 digital edition), did not lead to developing a common method of analysis of the phenomenon, or even a definition of the essay. Additionally, it was published in 1997, i.e. nearly twenty-five years ago; in all this time the essay has progressed into an interesting direction, particularly in the countries which formed on the remains of Yugoslavia.

I would like to propose a discussion on the modern essay which is developing in the Serbian culture, with special consideration of a variant which I would refer to as the feminist essay. This is how I term essays with emancipation and feminist themes, which have already developed a certain tradition in the Serbian culture ${ }^{3}$. They have surely had major impact on the conceptual formation of the women's movement in Serbia, particularly in the first half of the 20th century, and they reached excellence at the turn of the 21st century. They have also gradually influenced the change in women's awareness, supported the intellectual formations of their community, strengthened a special literary culture, and between that which is personal and that which is relational they have co-created a broader community of thinking and acting, charting a narrational map of various problems, thus promoting a critical analysis of tradition. The genre is currently a special kind of a polygraph which identifies and predicts changes occurring in a culture, and there were quite a few of those after the breakup of Yugoslavia and the war of 1991-1995. In recent history, it has also fulfilled the role of a tool for creating an analytical and methodological platform, and it has been a means of rapid anthropological and cultural analysis, and a form of transfer of social or philosophical ideas.

In the 1990s, the essayistic works by many female authors in the region entered a very important new stage. It was a stage of rebirth and of a transformation of the essay itself, which in many respects was exceptionally dynamic, and which offered inspiration for independent thinking and evaluations of

2 Encyclopedia of the Essay, ed. T. Chevalier, London-Chicago 1997.

${ }^{3}$ I have devoted several last years to studying this phenomenon, and I discussed tradition and the contemporary times in more detail in Mistrzynie myślenia. Serbski esej feministyczny (XIX-XXI wiek), which was published in the autumn of 2019 by Adam Mickiewicz University Press in Poznań. I devoted a considerable portion of the book to Svetlana Slapšak. I based this article herein on that particular research and fragments of the book. 
the situation. The necessity to find oneself intellectually and institutionally in the new situation after the Yugoslav Wars and the breakup of Yugoslavia - as well as in the phase of creating new identity narratives and redefining the existing ones - certainly fostered the wandering attitude (e.g. emigration or seeking refuge, since inconvenient male writers and female writers/essayists who openly criticised the realities of the newly-established states were forced to leave their countries) and a reflection recreated in the 'nomadic' genre, i.e. the essay. This is because, as Tatjana Rosić wrote, the essay at the turn of the 21st century has the qualities of a genre which is, in a sense, nomadic, since, according to its genological nature, it constantly wanders between topics, problems, and ideas. Its unstable and variable structure seems the perfect medium for a constant transforming of fluid identity. It also matches the experience of an outcast from own country, from own culture (surely from its main course), and, partly, also from the language. Since the nature of the essay consists of its ability to enter into close relations with historic moments (today even with the situation of redefining or dismantling the markers of a civilisation), during the breakup of Yugoslavia it became, as Rosić argued, a convenient genre for redefining the outcast situation and for reflecting on the phenomenon of migration and the condition of migrants owing to the fact that within it there are intertwined memory and forgetting, melancholy and euphoria, ideology and aesthetics. It became a genre which at the end of the 20th century in Yugoslavia defined the limits of the zone of Otherness/ Difference - especially regarding the excluded and the marginalised, which - in the situation of war that entailed the process of repatriarchalisation, also applied to women. For those reasons, in my opinion, at the turn of the 21st century the essay (re)gained its due dignity as a genre, and since the feminist essay has not previously had a clearly defined or stable position in literature, the female authors, marginalised, were even more entitled to engage in such writing with great passion. This has supported the development of a new discourse in opposition to the official ideology promoted by the authorities. This kind of essay has also become a part of the strategy of resistance to the repressive and nationalistic regime, enabling (post)Yugoslav female intellectuals to seek alternatives and create a mental 'diagnostic apparatus'.

A major factor in the development of the feminist essay in the 1990s was, as Judita Šalgo (1941-1996) argued in 1994, the compactness, fragmentariness, and the ease of packing within its framework fragments of own life and experience, i.e. that which has constituted the immanent feature of this form since its beginnings:

Life can be stored the longest in classical genres, in reliable narrative poems and novels, constructed out of a natural literary material, yet it can be packed the quickest and with most ease into the essay, that universal and portable form [emphasis - M. K.], which in this century of war-time escapes and interplanetary relocations could prove extremely important. ${ }^{4}$

${ }^{4}$ J. Šalgo, Četiri fantazije na temu: esej, [in:] eadem, Jednokratni eseji, ed. V. Pavković, Belgrade 2000, p. 114. Unless indicated otherwise, all quotations in English were translated from their Polish versions, which had been translated into Polish by Magdalena Koch. 


\section{Svetlana Slapšak's engaged essays}

Undoubtedly, Svetlana Slapšak (born in 1948) is one of the most important if not the most important - figures of contemporary feminist essay written in Serbian ${ }^{5}$. For the past three decades, she has exerted an immense influence on the shape of both the essay and the feminist thought developing in the states of former Yugoslavia. In the 1990s, Slapšak has assumed - somewhat predicting the concept of the new humanities - that thinking and writing is an active operation (writing as acting), which she often mentioned in interviews ${ }^{6}$ and texts ${ }^{7}$. For that reason, she has long referred to her essays as textual interventions that are supposed to produce a change of everyday life. Therefore, she believes in the causative nature of the essay and she has practised the essay in line with the thought which Ryszard Nycz referred to as "culture in action" or "participation culture", indicating a tendency of an action-focused model of culture, which is supposed to lead to practical outcomes, changes within the domain of worldview attitudes, mentality, sensitivity, identity, and experience - both individuals and communities actively participating in the projects being fulfilled ${ }^{8}$.

This would mean that the writing of essays in the spirit of feminism or from the point of view of gender has become for her an element of criticism and contestation, a gesture implementing the assumptions of "engaged humanities which undertake analytical interventions in the fields of social mentality, memory, and cultural identity" . It is a result of "distrust and opposition to existing conventions ${ }^{110}$, and it accumulates the power to object not only to the existing literary and cultural field, but also to the socio-political one. The essay as a form of expression became for her the embodiment of engaged humanities, meaning that Slapšak practises "the humanities which are practical, performative, active - the humanities of action"11, which cannot be reduced to pure contemplation of the world but, rather, has the ambition of changing it or influencing the changes occurring in it. The contemporary formula of the feminist essay fulfils this task very well.

On top of that, the feminist-anthropological perspective proves a major feature of Slapšak's texts. One could say that her essayistic activities are to a large extent based on her notion of personal causativeness - which some

${ }^{5}$ However, I must admit that other contemporary Serbian female essayists (Judita Šalgo, Žarana Papić, Jasmina Lukić, Ljiljana Đurđić, Radmila Lazić, Nada Popović Perišić, Biljana Dojčinović, Dubravka Đurić, Tatjana Rosić) or Croatian female essayists (Dubravka Ugrešić, Slavenka Drakulić, Rada Iveković, Andrea Zlatar) - to mention only the major ones - deserve to be discussed in separate studies or even a stand-alone monograph.

6 Линија испод које се не може ићи, Разговор са Светланом Слапшак водиле Биљана Дојчиновић и Ана Коларић, „Књиженство: часопис за студије књижевности, рода и културе", 6/2016. http://www.knjizenstvo.rs/magazine.php

7 Cf. S. Slapšak, Žene, Jugoslavija, antikomunistička narkoza i novi kolonijalizam: mape, putevi, izlazi, "Poznańskie Studia Slawistyczne" 2013, issue 5, pp. 249-263.

${ }^{8}$ R. Nycz, Kultura jako czasownik. Sondowanie nowej humanistyki, Warsaw 2017, p. 63.

${ }^{9}$ Ibid., p. 163.

${ }^{10}$ E. Domańska, Historia egzystencjalna. Krytyczne studium narratywizmu i humanistyki zaangażowanej, Warsaw 2012, p. 157.

${ }^{11}$ Ibid., p. 151. 
might find naive - and on the ethics of responsibility and activism. Particularly after the war in the 1990s, which brought about the breakup of federal Yugoslavia, i.e. in a time of redefining the reality and various reckonings, the fact of practising a responsible essay from the position of personal experience while considering women as people became a key issue for the authoress. Her critical polemic expressed in her essays resembled the mode of developing the citizenry reflection. In 2007, she wrote:

The deconstruction of the post-war culture requires not only an anthropological analysis but also a polemic. (...) There are no more grand fronts nor minimalistic requirements which everyone would have to accept; nor is there a collective false majority-based energy of the necessary opposition. No one is simply "ours" anymore, nor am I "we". It is high time to establish the criteria of severe criticism to have a focussed view. ${ }^{12}$ (emphasis - M. K.)

Through essays, Slapšak focused and personalised her view. She spoke based on personal experience, her own knowledge, and the feminist views she had. When she wrote about Slapšak and other female authors, Tatjana Rosić aptly noted that the feminist essay at the turn of the 21st century became in the Serbian culture a diagnostic genre and a comprehensive political undertaking which triggered the thinking about the future of post-Yugoslav narrative ${ }^{13}$. Through the prism of self-referential analytical and textual practices, this form opposes the community of silence; it has become a tool for the feminist criticism of the phenomenon of repatriarchalisation (backlash), which - since the war - nationalistic right-wing groups have tried to implement in the national states forming anew on the remains of Yugoslavia. Slapšak wrote about the return of the masculinisation of public space during the war and after it, and about the re-exclusion of women from anything which was not reproduction or feeding the nation. Therefore, her version of the essay tried to deconstruct the collective ideology of the 'national community', and she provided feminist readings of 'nationality', 'nation', and 'memory' (or, rather, of the processes of controlled amnesia, intentional forgetting or ousting inconvenient topics and forging the past). For individual representatives of civic individualism, it was the essay that became a privileged genre, the best medium for articulating the critical and polemic feminist vision of the post-war world. It became a major personal trace being left in the culture. There is, as Rosić stressed, another side to the phenomenon. As the author states, "Nonetheless, there is still apprehension about feminism as a minority movement which produces «minority» knowledge, which is marginalised, and which will never have the same status as the hegemonic narrations of a «universal» nature"14.

${ }^{12}$ S. Slapšak, Uvod, [in:] eadem, Mala crna haljina. Eseji o antropologiji i feminizmu, transl. from Slovenian J. Petrović, Belgrade 2007, p. 10.

${ }_{13}$ T. Rosić, Feministički esej u srpskoj književnosti i raspad Jugoslavije, "Književna istorija" 2015, vol. XLVII, issue 157, p. 244.

${ }^{14}$ Ibid., p. 241. 
Svetlana Slapšak's voice became that clear and leading voice of personal opposition not only in Serbia, but also throughout the region. For Slapšak, the ethics of feminism has often been more important than the mere aesthetic factor. A distinct feature of her language was the feminist reading of the nation and war-time experience as an experience of sexes juxtaposed with the corrupt Balkan system of "brotherhood at rule following the tribal/totalitarian framework ${ }^{\prime 15}$. The essay became for her a medium through which she changed the political discourse of "brotherhood and unity" to an alternative discourse of "sisterhood and diversity". Thus, Slapšak turned the essay into a significant methodological instrument of literary criticism of pro-active cultural reflection.

In fact, since the 1990s Slapšak's essays have not been monolithic - they underwent an evolution under the influence of the authoress' new personal circumstances. On the one hand, I am referring to her fluctuations within the line from academic theoretical reflection (vita contemplativa) to social practice and activism (vita activa). On the other, then, to the issue triggered by the former one - from reflection on the current affairs associated with the 1990s wars, all the way to the post-war cultural anthropology trying to describe the mechanisms of culture from the position of an active female intellectual who tried to translate the former (Yugoslav, pre-war) culture to its new form (post-Yugoslav post-war situation), with all the changes brought about by the wars of 1991-1995. After decades of methodological studies in anthropology, philosophy (including classical), and sociology and feminism, for Svetlana Slapšak a theory must mainly be proven in action and trigger the nerve of activism and causativeness in order not to become petrified. Therefore, for years she has tried to find a method for transitioning from analysing the current political imagined world to a new articulation, and to create her own narrative-problem map of the post-Yugoslav feminism.

It is exactly the essay of the interventional character that became the proper genre for Svetlana Slapšak's activities, a trademark of intellectual thinking and diagnosing the social situation, including the contemporary situation of women. The writer has created in the post-Yugoslav region - i.e. not only in Serbia or Slovenia, but also in Croatia, Montenegro, Bosnia and Herzegovina, where her texts are published and read - a model of bold feminism, using nothing but the essay itself. In it, Slapšak successfully combines her expert theoretical knowledge and analytical critical mind with literary practice and engaged socio-political activism. Through the practice of the essay, she seeks a new language for the contemporary feminism and new form(ula)s for reading various phenomena, and, as a result, she still carries the postulate of the second wave of feminism formulated by Kate Millet, namely that "the personal is (still) political". Most of all, her writings reflect the influence of La French Theory, since already in the 1970s within the field of her intellectual impact there developed the Serbian (and, more broadly, Yugoslav) theoretical thought ${ }^{16}$. Such is

${ }^{15}$ Ibid., p. 245.

${ }^{16}$ Ewa Domańska wrote about the influence of La French Theory on the development of engaged humanities in Europe and the USA. Cf. E. Domańska, Teoria jako praktyka interwencji, [in:] eadem, Historia egzystencjalna..., pp. 150-155. 
the theoretical foundation of her essays, including the feminist ones. She indicated that women always lose as a whole when nationalists and their elites gain power. In many of her texts, she broadly diagnosed the phenomena of xenophobia and homophobia, framing them within the contexts of the repatriarchalisation of the society and the reactivation of nationalist politics in the newly formed national states. In this context, she diagnosed the position of women and described the changes through the prism of their experiences. She also examined the post-war (since 1995) democracy, to which she referred to as 'salival' (from the Latin saliva, meaning the same as 'saliva' in English), as it was used exclusively to vilify (by the figurative spitting on them) the Other (including women, the feminist movement, or the movements of other minorities). She strongly opposed the post-war processes of 'deculpabilisation' (from the English word 'culpable') of the Serbian culture, i.e. the politics of 'forgetting' and the suppression of own crimes committed during the recent war. During the war and a dozen or so years after it, the essay has mainly become a tool of liability in the post-Yugoslav context. It formed in the aftermath of a severe and tumultuous polemic with the mainstream. Slapšak sided with the civic resistance movement. In her hands, the feminist essay has become a special form of opposition, a critical practice which uncovers the roots of hegemonic patriarchy. Her essay is a mature genre, the best tool for expressing the feminist critical and poetological vision of the world. Slapšak has applied the category of sex onto cultural phenomena. In doing that, she professed the philosophy of wartime and post-war everydayness, one that is focused on its regular signs ${ }^{17}$.

Thus, she has fought for establishing new literary, academic, and intellectual criteria in the post-war cultures of Serbia and the region. One of the characteristic features of her essays is the creation of new terms which she usually derives from ancient Greek or Latin, as one could expect of a classical philologist (I have already mentioned the 'salival' culture or 'deculpabilisation'). This also translates into a refreshing of the form and role of the essay, and into new proposals for its existence, which is also expressed in the linguistic and terminological inventiveness. She branded some of her essays as chronospores ('chronospore': from the Greek chronos meaning 'time' and spore meaning 'seed'). Those essayistic and at the same time metaphorical short commentaries on the reality - peculiar "time seed" essays - mainly

17 In Poland, in her excellent and now classic essays, Jolanta Brach-Czaina wrote somewhat differently, i.e. in a philosophical and not anthropological manner, about the hustle and bustle and everydayness. Cf. J. Brach-Czaina, Szczeliny istnienia, Warsaw 2018. This collection of essays was first published in 1992 (Wydawnictwo PIW), and then in 1998 (Wydawnictwo eFKa). It became a major literary occurrence, being referred to - among others - as a cult book and "the bible of feminism" (due to its emphasis on the everyday roles of women). In a similar style, with an emphasis on the philosophy of existence, the authoress wrote another book which also became a cult item. Cf. J. Brach-Czaina, Błony umystu, Warsaw 2003. Here, she made an additional matrilinear author's gesture: she signed it as "daughter of Irena, granddaughter of Bronisława, great-granddaughter of Ludwika", thus opposing the phenomenon of structural amnesia (the fact of descent on the distaff side is carefully concealed in our civilisational practice, sentencing inter-generational bonds between women to be forgotten; women bear the names of their fathers and husbands). Cf. J. A. Barnes, A Structural Amnesia, [in:] idem., Models and Interpretations. Selected Essays, Cambridge 1947. 
assume present-day-related significance. Yet, according to the author herself, they can also develop their inherent potential, which can become active in another time after a period of their existence in the dormant form; then the essay will be able to disturb the existing reality. In other words, she sees the causative power of the essay also for possible future diagnoses.

In her essays, she tries to combine feminism which is "politically radical and theoretically refined at the same time"18. Yet, her activism is also fuelled by her deep academic consideration and reflection, saturation with experiences and deliberation on the issue of sex and gender and the tracing of the abuses of patriarchy. This should not be surprising to anyone as I am discussing the output of an authoress who is a familiar figure in the regional (both Yugoslav and post-Yugoslav) context and in the international context (both European and American) alike. She was born in Belgrade and at the local university she acquired all the academic degrees and titles: from a master's degree, through a doctorate, to becoming a professor. She is a specialist in classical philology, cultural anthropology, and women's and gender studies. In 1972-1988, she was a faculty member at the Institute of Literature and Art (Institut za književnost $i$ umetnost) in Belgrade. She was fired due to political turbulence and accusations. Since 1991, she has been living and working in Ljubljana, Slovenia, where she emigrated with her husband Božidar Slapšak, a Slovenian professor of ethnology. As a professor, she successfully - and with a theoretically-driven enthusiasm - developed in Slovenia studies of the anthropology of ancient worlds, gender studies, and Balkan studies at the highly appreciated Institutum Studiorum Humanitatis (ISH), a post-graduate faculty of the humanities in Ljubljana (since 1997), a doctoral school of which she was the dean (dekanesa) for a decade (2003-2013), where many significant doctoral dissertations were developed, including some under her direct supervision. She was a lecturer at the University of Ljubljana, where at the Department of Slavistics she taught courses in Serbian and Croatian literatures (1985-1992) as well as she ran a 'Balkan women' course (1995-2012) in a sociology-of-culture programme. She retired in 2014, yet she is still creative and intellectually active, still writing books and essays. She was the editor-in-chief of the ProFemina journal, published in Belgrade, which throughout its existence (1994-2011) had a huge impact on the feminist community in the region. In 2009-2013, she was the manager of the Serbian Cultural Centre Danilo Kiš in Ljubljana. She is the author of several dozen books: a dozen or so academic volumes and essay collections, two dramas, three novels, and numerous translations from ancient Latin and Greek, as well as from modern Greek, English, French, and Slovenian. She has recently published: Leon i Leonina (2014), Ravnoteža (2016) - for which she received the Zlatni suncokret ['Golden Sunflower'] award and the Peace Prize of the women's section of Slovenian PEN-Club - and Škola za delikatne ljubavnike (2018). One immediately notices the level of the knowledge and self-awareness of the intellectual, the theoretical knowledge of the professor,

18 J. Bednarek, Linie kobiecości. Jak różnica ptciowa przekształciła literaturę i filozofię?, Warsaw 2015, p. 167. 
and the fresh pen of the writer. The combination of all these abilities in the essay produces a completely new quality.

This is precisely what I am most interested in, i.e. her essay collections, including those with various awards, in particular those in which the sub-genre of the feminist essay developed, i.e. Mala crna haljina. Eseji o antropologiji i feminizmu $(2007)^{19}$, Ženske ikone XX veka $(2001)^{20}$, Ženske ikone antičkog sveta (2006) ${ }^{21}$, Antička miturgija: žene (2013), and - albeit to a lesser extent - Hronospore II. Eseji i komentari (2010) and Muške ikone antičkog sveta (2018). I would like to focus on a discussion of two strategies of Svetlana Slapšak's feminist essay: the interventional and polemic strategy on the one hand, and the academic strategy - which has developed the anthropological essay associated with the mythology of everydayness (modern and ancient) - on the other.

\section{Essayistic chronospores or the Little Black Dress}

I shall begin with the authoress' intervention essays, a good example of which is the already mentioned Mala crna haljina (Little Black Dress). The book was published in Serbian only in 2007, but it was first written in 1993 in Slovenian after the author had emigrated and that version was the basis for the Serbian translation (which, in fact, was published in Austria during the Yugoslav Wars). Therefore, it includes texts which were chronologically older, indicating the author's essayistic approach in the final decade of the 20th century. Even though the Serbian edition was reduced in size considerably, the seed essays of the yesteryear which were included in the collection were still sufficiently subversive. They openly indicated the disgrace and corruption of the Serbian establishment which was close to the authorities, the complicity of intellectuals in inciting the war (already by the end of the 1980s), the shameful lives of some of them during the war as the "classics of Serbian nationalism" (according to Slapšak, those included leading writers and intellectuals involved in the ideology, e.g. Dobrica Ćosić, Antonije Isaković, Milorad Pavić, Vidosav Stefanović, Predrag Palavestra, and more) ${ }^{22}$, as well as - after the war in the newly established national states - the glaring deficit of ethical capital among the representatives of the so-called political elite of the authorities. The uncompromising nature of this collection of essays also resulted from the fact that the authoress was interested, as she admitted in the "Introduction", in women and pacifists, i.e. two groups which - even though treated as minorities in the authorities' discourse - were in terms of their numbers a majority in the country, and yet their voice did not resonate in the public space. Through her essays, she also opposed the diktat of post-war Serbian democracy which she defined as 'salival', focused on vilifying its opponents and discrediting the Other

19 S. Slapšak, Mala crna haljina. Eseji o anropologiji i feminizmu... The book was first published in 1993 in Slovenian: S. Slapšak, Mala crna obleka, Ljubljana 1993.

20 S. Slapšak, Ženske ikone XX veka, Belgrade 2001.

21 S. Slapšak, Ženske ikone antičkog sveta, Belgrade 2006.

22 S. Slapšak, Mala crna haljina..., pp. 9-11. 
(including women/feminists). The personal dimension of this book is best expressed by the maxim "I write so that I can remember". For Slapšak, the essay became not only a tool of liability for her own vision of reality and for her reflection, but also - and mainly - a function of memory and a Barthesian method of the tradition of reading of mutually conflicted texts of everydayness. As she argued in one of her essays, "In fact, I cannot accept yet another attempt at pushing a critical voice (my voice) under the carpet only because it cannot be subjugated to either of the existing groups" ${ }^{\prime 23}$.

Mala crna haljina, translated into Serbian, appeared as a book published by the Women's Studies Centre (Centar za ženske studije) in Belgrade, i.e. by a centre of major importance for feminist reflection, as it was there that a new communicational and educational network was being developed, and Slapšak's voice was its major element. The very title of the collection, which doubled as the title of its opening essay, is telling. It constitutes a model of Svetlana Slapšak's essays.

First of all, central focus and reflection is placed on the symbolic attribute of femininity and fashion, the refined yet practical "short black dress" (la petite robe noire). The author treated it as "the most symbolic, provocative, socially most subversive element of women's clothing"24. The first text includes the trademark features of Slapšak's poetics as her feminist essay was written in the spirit of anthropological everydayness: she started with an everyday female detail, a practical garment for every occasion; she shortly outlined the differences between male and female perceptions of the 'little black dress' (LBD); from universal symbolism and history (as a Mediterranean additional to European fashion - the influence of Spanish and French traditions), she transitions from detail and her own experience (moment of purchase, the distinctive time of 1990, i.e. still before the war, and the purchase was made in the company of her friend, almost her peer Dubravka Ugrešić, also a well-known essayist) towards a broader anti-war context of the 1990s and the 'Women in Black' pacifist movement ${ }^{25}$.

The indicated attribute of femininity carries ambiguous coding, since symbolically it occupies a position between death (funeral clothing) and seduction (an all-purpose modest yet elegant evening dress for every occasion). In addition, it evokes fear, respect, and desire in men, conveying an immediate and clear social message from women's perspective. A female supporter of LBD tries to avoid being conspicuous and resort to modest minimalism on the one hand; however, on the other hand, she does not reject the seductive

23 Ibid., p. 128

24 Ibid., p. 15.

25 'Women in Black' (Nashim BeShahor in Hebrew) is an international women's movement which was originally established in 1988 in Israel during the first intifada. At that time, women in Jerusalem met every Friday, dressed all black, which was to indicate their mourning of the victims on both sides of the conflict. The movement later spread to other countries and it inspired feminist and peace movements around the world. It was particularly active during the Yugoslav Wars of 1991-1995 (the Belgrade Žene u crnom group - established on 9 October, 1991 - has existed ever since) and it carried the banners of anti-war, anti-military, anti-nationalist, anti-sexist, and anti-patriarchal slogans. Members of the movement oppose all forms of discrimination (based on sex, race, sexuality, or religion). See: http://zeneucrnom. org/index.php and womeninblack.org. 
quality which the piece of garment carries (a knee-long dress, fitted, and sometimes low-cut). The expanded semiotics of LBD refers to its history, i.e. to its symbolism as a strong expressive feminine sign within the public space.

In the book, most of the essays discuss the feminist movement and the women's perspective within the optics of the nationalist discourse. Her own voice, with which the author tried to co-create an alternative space of culture, also resonates in the text titled Feministički Rašomon (Feministic Rashōmon ${ }^{26}$ ), which discusses the domination of the male voice within public space, the complex history of feminism around the world, the past and recent errors, stumbles, and external prejudice in this regard, as well as the contradictions within feminist movements themselves, and the need to combine pacifism and feminism, and to create communicational networks between women. The authoress devoted several texts in the collection to outstanding though prematurely deceased much inconsolable fellow female writers: Biljana Jovanović (Biljana Jovanović (1953-1996))27 and Žarana Papić, a sociology professor, a feminist activist and essayist (Nepripadnost, rod, svojstvo, soj: o Žarani Papić $)^{28}$. She also reflected upon - and admired - the Italian journalist Oriana Falacci (1929-2006) in the essay Oriana Falači: punto e basta! ${ }^{29}$. Thus, action and thinking, writing and reading are all linked in Slapšak's works.

The difference of women's experience translates into existential and cultural capital introduced to the essay. The gender perspective allowed Slapšak and her readers to indicate various points of view and, at least this way, provoke polemics with the "holders of discourse". It is a tool useful in the feminist re-appropriation of discourses. It introduces a counter-discourse which constitutes an act of alternative communication and dialogue with the nationalistic framework of the Serbian culture; it demystifies the main discourse, which legitimised war and was openly anti-feminist and misogynous. Slapšak's feminist essay is anti-systemic; it opposes the trivialisation and falsification of history and tradition; it dismantles the myths of androcentric universal union; it demands that women be treated within the space of culture equally to men. Her critical analysis of tradition in the spirit of feminism stands against the existing ideology and prevents the feminist voice from being subdued.

\section{Icons and mythurgies in Svetlana Slapšak's feminist essays}

Another extremely interesting group of feminist essays - probably even more interesting that the former one considering the continuing applicability of the message - consists of essays collected in three books: Zenske

${ }^{26}$ S. Slapšak, Mala crna haljina..., pp. 63-69. In this instance, Svetlana Slapšak referred to the title of the famous 1950 film by Akiro Kurosawa, titled Rashomon, in which the same stories of violence and crime are perceived by each eye witness or participant in a completely different way: no one knows who the culprit and the victim are. Each party tries to vindicate themselves and incriminate others so that it is not possible to know for sure which of the accounts is true. Slapšak updated Kurosawa's construct and strategy to match the contemporary situation of the formation of the feminist discourse.

27 S. Slapšak, Mala crna haljina..., pp. 57-61.

28 Ibid., pp. 203-205.

${ }^{29}$ Ibid., pp. 121-126. 
ikone XX veka (2001), Ženske ikone antičkog sveta (2006), and Antička miturgija: žene (2013). The value of these three titles and their intellectual significance is best indicated by the fact that all three were published as the prestigious and known for high factual standards Biblioteka XX vek (Library of the 20th Century, since 1971) editions ${ }^{30}$. Within the already mentioned author-text constellation, the thinker is represented extremely well as six of her essay collections have been published in the series: apart from the above-mentioned three, to which I shall return in a moment, there were also collections of anthropological essays, e.g. Leteći pilav. Antropološki eseji o hrani (2014), Kupusara. Ogled iz istorijske antropologije hrane i seksualnosti (2016), and Muške ikone antičkog sveta (2018). I shall not discuss the last three books here - interesting and recommendable as they are - as they do not (fully) fit into the category of the feminist essay.

The first two books which discussed the notion of the icon stirred particular interest. In her initial remarks, the author stressed that she used the ancient Greek word eikon ( $(\dot{i} \kappa \omega \dot{\omega})$, which means both an image and a representation, content and description, a notion itself and its chain of associations. She avoided the first meaning of the icon as an East Christian religious painting, and instead referred in both her works to semiotic references discussing icons as signs based on major elements of the secular sphere of everyday life and model-building matters and figures which are role models or manifestations of meaning. In both books, an icon as a concentration of reference is the keyword. Since, however, the author used the term "female icons", it became clear that she intended for a (re)creation or extraction of the elements of the culture associated with the broadly understood notion of femina, and the crystallisation through essays of the cultural history of women presented in the form of short several-page-long texts centred around the titular notion. The alphabet is the principle which structured the material of all three of the mentioned books. It is understandable considering the fact that thus organised individual figures, notions, and phenomena acquire a neutral non-hierarchic character; a list based on one's own selection of notions. Thus, there formed a special lexicon, an abecedarius of issues important to women and feminism. The arbitrariness of the organisation does not indicate any authorial preferences as to importance (by introducing order, an alphabetic approach somewhat seduces one with its 'objectivisation'), which is beneficial

${ }^{30}$ In it, there are published academic books and essay collections by both domestic Serbian (or regional) authors and foreign authors discussing a broad range of anthropological issues. The purpose of the edition was to enable Serbian readers to become familiar with the recent thoughts from the modern world as well as with the latest authors. Authors whose books were published in this intellectual series include, e.g., Clifford Geertz, Roland Barthes, Edward Said, Claude Levi Strauss, Mary Douglas, Mikael Herzfeld, Vladimir Propp, Maria Todorova, Arjun Appadurai, Aleida Assmann, Thomas Hylland Eriksen, to mention only the major figures. As for regional authors (from the states of the so-called former Yugoslavia), the series included works by its founder and head editor Ivan Čolović, an outstanding intellectual and Romanist scholar, and by other great minds, e.g. Božidar Jezernik, Žarana Papić, Mitja Velikonja, Dubravka Stojanović, Ranko Bugarski, Predrag Piper, Dunja Rihtman-Auguštin, Miljenko Jergović, Muharem Bazdulj, and more. Poland was also represented in this circle by the books by Roch Sulima, Krzysztof Czyżewski, Andrzej Mencwel, and the Polish-Albanian anthropologist Rigels Halili. 
to readers as they do not follow other people's tastes and they can read essays in any non-linear order without losing anything of the original intent. At the same time, the essay as a form automatically presumes the subjectivity in the selection of topics and in the approach to them. All three books have a somewhat enumerative character; they constitute lists of discussed issues which, if necessary, could be later complemented (even independently by readers) without harming the entire concept.

The first of the books, i.e. Ženske ikone XX veka [Female Icons of the 20th Century], has been composed by the essayist of model-building persons, figures, and notions which seemed to her more or less representative of the 20th century as they created the cultural paradigms of femininity. It consists of sixty essays which can be divided into several categories. One of these consists of model-building icons on the global scale, and the starting point is an autobiographical essay as it mentions actual people - e.g. Agatha Christie - and female writers whose names are usually associated with the development of the principles of feminism: Virginia Woolf, Gertruda Stein, Margarite Duras, and Rebecca West, or Angela Davis who fought for the rights of African Americans. There are also actors who were icons of sex and femininity, e.g. Brigitte Bardot, Marlena Dietrich, Anna Magnani, Mellina Mercuri, Jeanne Moreau, as well as a Mexican painter Frida Kahlo. There is Maria Skłodowska-Curie, a scientist and the biggest - according to Slapšak - intellectual icon of equality between the sexes. There is Taslima Nasrin, a Bengali feminist and activist of the women's movement. There is Valentina Tereshkova, the first female astronaut. There is Juliette Greco, a singer and a muse of existentialists. And there is Wilma Rudolph, a black sportswoman. There also appear categories of women who represent attractive and more or less desirable qualities, e.g. Ballerina, Nurse, Diva, Feminist, Princess, Vamp, 1920s female film character; or professions, e.g. Model, Journalist, Secretary, Worker, Partisan, Muse; or local ethnicity (Balkan woman, Romani woman). In the essays, there also occurs the iconisation of everyday items associated with femininity, e.g. underwear, flowers, a hat, a swimsuit, legs, perfume, trousers, a cigarette, needlework, a sewing machine, and a scales. Additionally, the categories of female relationality within the public and private spheres are described: woman and ideology (Žena $i$ ideologija), woman with a vacuum (Žena sa usisivačem), woman with a veiled face (Žena pod velom), and a female driver (Volan). The author offers an array of possible readings and interpretations of these categories, thus creating a series of historical and anthropological references to femininity; she weaves a web of references which become useful in mapping the 20th-century feminism.

Slapšak applied a very similar device of the iconisation of female figures in the second book, i.e. Ženske ikone antičkog sveta (2006) [Female Icons of the Antiquity]. This time, she used ancient Greco-Latin mythology and once again focused on reading it from the feminist position. The reading of past myths is accompanied by contemporary interpretations, updates of those, and a conviction of the inexhaustible freshness and the re-emerging (also manipulated) application of myths. For this purpose, the author developed a collection of seventy-seven mythical figures: from Aphrodite, Alcmene, 
and Arachne; through Danaid, Aegina, Europa, Flora and Fauna, Hera, Iphigenia, Cassandra, and Cybele; to Medea, Nymphs, Pandora, Penelope, Rhodopis, Theano, and Vergina. She was interested in two areas: firstly, the narrative core of myth and, secondly, the intertwining of symbolic meanings and their contemporary updating as well as the paradigmatic nature of female icons of antiquity and their narrative application within the current gender studies. At the same time, as an added value, these devices offer a refreshed modified form of the anthropological essay, which enriches the contemporary discourse with a distinctly defined feminist perspective. The author was mainly interested in the principles of including women in mythology within the framework of past patriarchal procedures, the modes of creating a feminine cult, the very process of mythicisation and modification of myths, and their endless capacity and the ability to utilise them under any historical circumstances and conditions. At the same time, the author argued critically against abusing and manipulating myths, and the processes of iconisation of myths that she uncovered became for her the outcome of the processes of the everyday work of cultural memory. In each of the essays about particular mythical female figures, she posed questions regarding their contemporary functions, the memory of them, and the adjustment of meanings to the contemporary needs. Yet, she did that in a style made possible by the very utilisation of the essay as a genre: with the learned knowledge of a professor of classical philology combined with the musings by a contemporary feminist armed with theoretical knowledge. However, the author enriched these essays with a pinch of personal irony and distance. She utilised mental shortcuts and fragments while maintaining the whole in a light and literary tone.

The continuation - or, rather, a conceptual expansion and supplement - of the book on female icons of antiquity came in the form of her next work, titled Antička miturgija: žene [Ancient Mythurgy: Women]. Even its introduction bears a symptomatic title which combines both publications, namely "Uvod. Miturgija ili druga knjiga ženskih ikona antičkog sveta" ("Introduction. Mythurgy or part two of female icons of the antiquity"). This time, the essayist no longer referred to icons of culture, nor did she interpret them. She focused on the narrative paradigm: the mechanism of constructing stories about female figures in Greek myths. Thus, she introduced the notion of mythurgy, which she understood as the contemporarily applicable mode of discussing myths and as the analysis of the methods of reading mythology. One can sense in it a clever blending of the words myth and liturgy, signifying a ritual, a mystery, a kind of an initiation. Then, in the combination with the titular object ("mythurgy: women"), the book discusses narratives which enable the mythurgisation of women. Mythurgy, according to the definition offered by the author in the introduction, refers to the methods of approaching myths, to stories about stories, narratives about narratives, which, however, include a series of contradictions:

Mythurgy as a term emerges from the approach to myth (...) it talks about telling a story (...) a myth is a story defined by a context and the mode of 
narration and listening/reading, yet it does not explain, normalise, or legitimise anything, it does not direct or inform anyone, it only seduces and leads to repeating a narration, as well as to thinking. ${ }^{31}$ (emphasis - M. K.)

This time she was also interested in mythology as a kind of linguistic strategy and a method of narration, as well as the result of extensive knowledge about language. But mainly it enabled her to reach "the instances when myths were abused in the recent history of the region where I was born"32, presumably referring to Serbia/Yugoslavia, possibly more broadly to the Balkans. In this book, when compared to the previous ones, one will find in the introduction more self-reflective remarks explaining the evolution of Slapšak's own approach to the anthropology of antiquity. She mentioned her two major authority figures who led her to that mode of thinking. These were Roland Barthes with his concept of everyday myths associated with the production of myths in the past, and Jean-Pierre Vernant ${ }^{33}$, who focused on the figure of the mythographer, a professional, the person who invents, compiles, records, and sells myths ${ }^{34}$. Svetlana Slapšak was interested in the mechanism of stereotypisation of myths and how it is abused in the creation of the discourse of the authorities. Slapšak refers to the mythographer/ professional using Vernant's referent of the "technician" of myths (,tehničar" mita); the historian was essential to her as a figure indicating that the act of telling myths does not entail any rituals, cult, faith, or philosophy, i.e. higher spheres of thinking, but that it involves the method of opposing any higher authority instead. Thus, mythical narratives through the process of mythicisation are reclaimed for the broader social context. In the second part of the title and throughout her book, Slapšak clearly referred, though, to female figures in ancient mythurgy; to the methods of introducing them into mythology and their later usage. The feminist reflection showing the process of utilising notions within this concept was of fundamental importance to her. She was interested, just as Barthes was, in interventions into myths, into the development of myths, the communicational control over myths maintained by authorities; not their "eternal", psychological, or anthropological universality etched in the Western line of thinking. For this reason, too, Svetlana Slapšak is, in my opinion, a symptomatic and unique figure for the Serbian feminist essay.

In order to illustrate the author's method, allow me to discuss the first of the book's fifty-five essays, titled Amazonke: mit o muškim strahovima (Amazons: Myth about male fears), as its model of narrative about ancient mythurgy of women is similar to that applied in the remaining essays. At the very beginning, the author indicated the thesis on the foundations of the Amazon

${ }^{31}$ S. Slapšak, Uvod: Miturgija ili druga knjiga ženskih ikona antičkog sveta, [in:] id., Antička miturgija: žene, Belgrade 2013, p. 10.

${ }^{32}$ Ibid., p. 11.

${ }^{33}$ Slapšak referred to the series of lectures by Jean-Pierre Vernant, which he delivered in 1996 in Ljubljana at the Institutum Studiorum Humanistatis as part of the Anthropology of Ancient Worlds programme, which she had co-created.

${ }^{34}$ Cf. S. Slapšak, Uvod: Miturgija ili druga knjiga ženskih ikona antičkog sveta, [in:] id., Antička miturgija: žene..., p. 9. 
myth: warrior women who generate male fear. She discussed the ancient mode of thinking of Greeks about women as a "different race" (druga rasa), positioned between livestock and barbarians (aliens), which constituted the cause of the chaos in the otherwise well-organised male world. The myth about the dangerous women appeared within the Greek imagined map of the world - as Slapšak interpreted it further on - for political reasons: the ideological paradigm of scaring men with the independence of women and a struggle between the sexes. The essayist saw the ideological plain of the myth in the efforts to maintain the thought of the need to tame the 'wild' female nature, and she saw its manipulative strength in the lack of a narrative whole of the myth as it was only based on the typical fragments of visualisation (women without the right breast, androphobic, using men solely for the purposes of fertilisation or as slaves, and raising daughters to become warriors). Slapšak referenced historically subsequent mechanisms expanding the framework of the myth: in Western cultures the designation of Amazon was applied to independent women who found in the myth traces of the European culture of matriarchy. Nonetheless, in the 19th century, an 'Amazon' referred only to an elegant woman of the gentlefolk, who practised horse-riding or who accompanied men in hunting. Slapšak disavowed the colonisational power of the myth and indicated how it was 'exported' even outside Europe: the fact of naming the longest river in the world the Amazon (presumably stressing its wilderness, natural primitiveness, inaccessibility, and lack of civilisation) - and the region in South America as Amazon - are clear symptoms of colonisation, i.e. imposing the trademarks of the European culture on other cultures around the world, thus imposing own evaluative paradigms. Another stage of the mythurgisation of Amazons is the contemporary shifting of the myth towards a dialogue between matriarchy (its utopia) and patriarchy (a concrete concept $)^{35}$.

According to the authoress, the narrative is necessary today only to show the process of the "struggle of the sexes" and that the times of women have passed and the time for men's rule has come. Based on this description in the five-page-long essay, one can infer the rules of mythurgisation: the starting point is a myth or its variants (ancient Greek and/or ancient Roman), next the historical general discussion tracing the presence of the myth in arts (literature, theatre, painting, sculpture, film), and then its various permutations and cultural adaptations in time and (geo)space. Thus, the myth is first recalled, then it is updated to include the feminist interpretation, and new meanings are assigned to it.

What was important to the Serbian essayist, as she herself declared in her texts, was the therapeutic communication with past myths of everyday life, updating their meanings, and the modes of establishing links with other cultures, but also the ethical basis of this dialogue with the past and, most importantly, the discovery of the paradigm of myth creation; the transition

${ }^{35}$ It is regretful that the author did not include one more, the most recent meaning a medical one - of Amazons, i.e. women suffering from breast cancer who had to undergo mastectomy, which is removal of a breast. Also missing from the narrative are 'Amazons Clubs' established by those women. 
outside the autism of national mythology and mythology as the source of collective identity, and their communicational intentions. Svetlana Slapšak used this inspiration to develop her own essayistic discussion; she crystallised her views through such texts; she performed a deep revision of culture; and she used the practice of her own "Yugoslav feminism", as she herself called it, in order to discuss mythological stories from the women's perspective in general. Thus, the author opposed all kinds of authority, and her essay strengthened and personalised the form and style of the contemporary Serbian feminist essay, giving it a new format. Apart from a focus on knowledge and polyglotism, it offers freedom unconstrained by the modes of thinking of others. Svetlana Slapšak has created a new quality within the existing essayistic form. She thus became for her contemporaries a master of independent thinking and courage, making her polemic voice clearly heard. Her essays sparkle with brilliant observations which do not obscure her devotion to facts, and her sensitivity to women's issues goes hand in hand with the engaged and refined form. With her new and updated reading of the signs of the European culture (including its sources located in the mythology of antiquity), Slapšak created an interesting narrative, intentionally opening several 'Pandora's boxes'. First of all, the anatomy of the paradigm of iconisation and mythurgisation enables one to uncover the mechanisms of manipulating myths in the history of one's country. Secondly, the re-thinking of ancient myths - associated with figures of femininity - has, in Slapšak's case, as I have already mentioned, therapeutic significance: she uses the material of ancient myth to diagnose which contemporary challenges the space of mythurgy faces in relation to the cultural role of women. Thirdly, she indicates the power of communication/ dialogue with both former myths and their new updated meanings emerging within the line continuation-rupturing-defining new paths for myths, often contrary to their general understandings (e.g. the myths about Xanthippe ${ }^{36}$ or Aspasia $^{37}$ ). Most of all, the three books discussing icons and the mythurgy of femininity indicate the potential and power of the feminist perspective and a re-vision of the figures of women who exist in culture. The contemporary essay became for the authoress the best form of alternative and independent thinking, a genre of intellectual intervention, thus becoming an excellent medium and example of the humanities in action.

\section{REFERENCES}

Barnes J.A., A Structural Amnesia, [in:] J.A. Barnes, Models and Interpretations. Selected Essays, Cambridge 1947.

Bednarek J., Linie kobiecości. Jak różnica płciowa przekształciła literaturę i filozofię?, Warsaw 2015.

Brach-Czaina J., Błony umystu, Warsaw 2003.

36 S. Slapšak, Ksantipa, ženomrzački mit, [in:] eadem, Antička miturgija: žene..., pp. 133-137.

37 S. Slapšak, Aspazija, osuđena na mit, [in:] eadem, Antička miturgija: žene..., pp. 39-43. 
Brach-Czaina J., Szczeliny istnienia, Warsaw 2018.

Chmielewska K., Jak możliwa jest poetyka (eseju)?, “Teksty Drugie" 2001, issue 3/4, pp. 134-138.

Domańska E., Historia egzystencjalna. Krytyczne studium narratywizmu i humanistyki zaangażowanej, Warsaw 2012.

Encyclopedia of the Essay, ed. T. Chevalier, London-Chicago 1997.

Epshteyn Mikhail Naumovich, Paradoksy Novizny. O literaturnom razvitii XIX-XXvekov, Moskva 1988.

Hilsbecher W., Esej o eseju, [in:] W. Hilsbecher, Tragizm, absurd i paradoks. Eseje, selection and introduction by S. Lichański, transl. S. Bałut, Warsaw 1972.

Linija ispod koje se nemozhe iћi, Razgovor sa Svetlanom Slapshak vodile Biљana Dojchinoviћ i Ana Kolar, „Knjizhenstvo: chasopis za studije knjizhevnosti, roda i kulture", 6/2016. http://www.knjizenstvo.rs/magazine.php

Markowski M.P., Czy możliwa jest poetyka eseju?, [in:] Poetyka bez granic: Z Dziejów Form Artystycznych w Literaturze Polskiej, eds. W. Bolecki, W. Tomasik, Warsaw 1995.

Nycz R., Kultura jako czasownik. Sondowanie nowej humanistyki, Warsaw 2017.

Rosić T., Feministički esej u srpskoj književnosti i raspad Jugoslavije, "Književna istorija" 2015, vol. XLVII, issue 157, pp. 233-254.

Sendyka R., Nowoczesny esej. Studium historycznej świadomości gatunku, Kraków 2006.

Sendyka R., Od kultury "ja” do kultury "siebie". O zwrotnych formach w projektach tożsamościowych, Kraków 2015.

Slapšak S., Mala crna haljina. Eseji o anropologiji i feminizmu, transl. from Slovenian J. Petrović, Belgrade 2007.

Slapšak S., Žene, Jugoslavija, antikomunistička narkoza i novi kolonijalizam: mape, putevi, izlazi, "Poznańskie Studia Slawistyczne” 2013, issue 5, pp. 249-263.

Slapšak S., Ženske ikone XX veka, Belgrade 2001.

Slapšak S., Ženske ikone antičkog sveta, Belgrade 2006.

Šalgo J., Četiri fantazije na temu: esej, [in:] J. Šalgo, Jednokratni eseji, ed. V. Pavković, Belgrade 2000.

The Politics of the Essay. Feminist Perspectives, eds. R.E. Boetcher Joers, E. Mittman, Bloomington 1993.

\section{SUMMARY}

The article discusses the problem of the theory and practice of contemporary Serbian feminist essay. The text indicates how - at the turn of the 21st century - the essay participated in the reading of the nationalist culture of fear during the breakup of Yugoslavia, how it became the tool for creating an analytical and methodological platform and a means of quick anthropological and cultural diagnoses, as well as a form of transfer of social or philosophical notions. This new strategy of the essay was illustrated through the examples of books by Svetlana Slapšak, a leading figure of the (sub)genre in the Serbian culture, a professor of cultural anthropology, classical philologist, and feminist critic: Mala crna haljina. Eseji o antropologiji i feminizmu (1993/2007, Little Black Dress. Essays on Anthropology and Feminism), Ženske ikone XX veka (2001, Female Icons of the 20th Century), Ženske ikone antičkog sveta (2006, 
Female Icons of the Antiquity), Antička miturgija: žene (2013, Antique Mythurgy: Women). It becomes clear that one of the trends of the contemporary essay in the Serbian and post-Yugoslav cultures is the application of the genre in the spirit of modern engaged humanities and textual intervention.

\section{Keywords}

Serbian contemporary essay, feminism, textual interventions, power of objection, Svetlana Slapšak

Magdalena Koch - professor at the Institute of Slavic Philology, Adam Mickiewicz University in Poznan, head of the Balkan Gender and Trans-Cultural Studies Research Unit. Her academic research interests include the study of history of Serbian, Croatian, and Bosnian literatures of the 19th, 20th, and 21st centuries; gender studies; Serbian feminist essay; Serbian and Croatian modern drama and theatre; the studies of Sephardi Jews in the Balkans. She is the author of the following monographs: Podróże w czasie i przestrzeni. Proza Isidory Sekulić (2000), ...kiedy dojrzejemy jako kultura... Twórczość pisarek serbskich na początku XX wieku (kanon - genre - gender) (2007; supplemented and expanded edition in Serbian: Belgrade 2012), and Mistrzynie myślenia. Serbski esej feministyczny: XIX-XXI wiek (2019). She is also the co-author of the monograph titled Milena Pavlović Barilli EX POST (Belgrade, 2009). She was the thematic editor of an issue of the "Poznańskie Studia Slawistyczne" journal (Gender Theories and Practices in Slavic Cultural Texts. Innovation - Inspiration - Interpretation, 11/2016), and of the "Studia Judaica" journal (Strategies of Survival: Balkan Jewish Women and Cultural Representations of Memory 2018, no. 1, issue 41, in collaboration with Katarzyna Taczyńska). She translates from Serbian, Croatian, and Bosnian prose (Miloš Crnjanski, Miroslav Mićanović, Nenad Veličković, Damir Arsenijević), drama (Tanja Šljivar, Ivana Sajko, Lada Kaštelan, Adnan Lugonić), and poetry (Dubravka Đurić, Ferida Duraković).

e-mail: magdalena.jolanta.koch@gmail.com 